\title{
EXPERIENTIAL FOUNDATIONALISM, LINGUISTIC PRACTICE, AND HISTORICITY ${ }^{1}$
}

\author{
WOJCIECH MAŁECKI
}

In what was to become his last book ever written, the late Richard Rorty observed, with sad resignation, that rarely does one encounter today philosophers who possess the virtue of "ambidexterity", by which he meant the ability to feel at home in both analytic and continental thought - the freedom to "easily turn from Rawls to Carl Schmitt, or from Derrida to Wittgenstein, or from Foucault to Christine Korsgaard" (Rorty 2007, 120). Colin Koopman is definitely one such philosopher. But he is even more than that, for besides moving effortlessly and confidently between Michel Foucault and Bernard Williams, Slavoj Žižek and Michael Walzer, he also shows remarkable competence in pragmatism, both classical and contemporary, including the thought of Rorty himself. As a pragmatist sympathetic to Rorty, I would like to particularly emphasize this latter feature of Koopman's erudition because if said ambidexterity is indeed something exceptional nowadays, then (even more) so is a genuine understanding of Rorty's oeuvre; an understanding that would be free from the various clichés that surround it and could engage it with all the seriousness and intellectual sensitivity it deserves. Moreover, given the character of Koopman's book I could also say that he has certainly inherited from Rorty an ambition to spin sweeping narratives in intellectual history ${ }^{2}$ (ones whose aim, importantly, is not so much a perfect rendering of the past, but rather the transformation of the present towards a better future), and that the traces of Rorty's influence are clearly visible in the phraseology of Koopman's discourse, too. For instance, whenever he says "we pragmatists" think $x$ or $y$, or should do $x$ or $y$ (see, e.g., Koopman 2009, 48, 85, 123, 208), this is a clear intertextual nod in Rorty's direction, ${ }^{3}$ and likewise for phrases such as "playing pragmatism and genealogy off of each other" (Koopman 2009, 227). ${ }^{4}$

\footnotetext{
1 Koopman, Colin. Pragmatism as Transition: Historicity and Hope in James, Dewey, and Rorty. New York: Columbia University Press, 2009, 288 pp.

2 Koopman himself gives Rorty credit for being "one of our most insightful intellectual historians of twentieth century philosophy" (Koopman 2009, 91).

3 This phrase is in fact so characteristic of Rorty that it has even become the subject of a vicious parody written by Susan Haack. See Haack 1998.

4 Cf., e.g., Rorty 1991, 14; Rorty 1989, 80; Rorty 1982, 6; Rorty 1991, 25; Rorty 2007, 30.
} 
It would be a gross misunderstanding, however, if someone got the impression that Koopman is a Rorty clone. ${ }^{5}$ After all, his main pragmatist hero is not Dewey, as was the case with the latter, ${ }^{6}$ but James, ${ }^{7}$ and he also, to use a euphemism, has much more sympathy for the notion of experience, celebrated by classical pragmatism, than does Rorty. In fact, the goal that Koopman explicitly sets for himself in Pragmatism as Transition is to go beyond the quarrel between what he calls "classicopragmatism" (the thought of James, Dewey, Peirce, et al.) and linguistic pragmatism (as represented by Rorty, Robert Brandom, and Hilary Putnam, among others), where "going beyond" does not mean forgetting or evading, or circumventing the two, but rather taking "what is best" in what they differ on, taking "what is best" in what they share, and then developing this material in the direction of a new, "third-wave pragmatism," which he announces under the name of "transitionalism" (cf. Koopman 2009, 3 ). Thus it is only natural that Koopman begins the book by elucidating the idea of transition as the structuring core of his "renewed" pragmatism. Having done so, he then demonstrates, in a historical sketch painted with a rather broad brush, how this idea has permeated, albeit in an underdeveloped form, all previous forms of pragmatism. And finally he indicates the advantages of reconstructing in terms of transitionalism some crucial philosophical debates taking place on both the intra and extra-pragmatist turf (the debates between: experientialism and linguisticism in epistemology; deontology and utilitarianism in ethics; utopianism and dystopianism in political theory), crowning his reflections-in the final chapter-with the methodological proposal of coupling Dewey's "idea of reconstruction" with Foucault's genealogy. In this way he tries to

show how pragmatists can finally offer convincing responses to two criticisms that have been persistently pressed against pragmatism for well over a century now: namely, the related criticisms that, first, pragmatism is Panglossian in downplaying the place of the tragic in our lives, and, second, that it is Promethean in overemphasizing the prowess of instrumental means-end rationality (Koopman 2009, 10).

As one can see from this summary, the book must bring a real embarass de richesse to any commentator, and henceforth it is really hard to do justice to it in a review essay like this, especially given that the breadth of Koopman's references, the freshness of his approach, and the ingenuity and clarity of his argumentation make each and every part of the book interesting and intellectually rewarding. Faced with the dilemma of either covering the whole text at the price of generality and simplification, or zeroing in on some of its threads and leaving others aside, I have decided to choose the second option and say a few words on a particular element of Koopman's book that I consider most important, namely, his treatment of the role of language and experience in pragmatism; a judgment that is, I must confess, biased by my own research interests. ${ }^{8}$

\footnotetext{
5 Even if he at times does not hesitate to "parrot" - the word is his-Rorty (Koopman 2009, 119).

6 In Rorty's own words: "The philosopher I most admire, and of whom I should most like to think of myself as a disciple, is John Dewey" (Rorty 1996, 32). Cf. Koopman 2009, 3.

7 "[T] he pragmatist who I most often find closest to my own transitionalism . . . [is] William James" (Koopman 131). Cf. Koopman 2009, 12.

8 See Małecki 2008, an English version of this paper is included in Chapter 1 of Małecki 2010.
} 
But let me begin with the questions I suppose most readers have had on the tip of their tongues for a while: what is transitionalism? How should pragmatism be seen as transition?

Here is Koopman in his own words: "Transitionalism can best be described as a philosophical temperament that focuses ideas, concepts, and things in terms of the way in which they are both part of and constitutive of transitional processes" (Koopman 2009, 11). And "transitionality," in turn, "connotes purposive change in light of the shifting circumstances of temporal and historical context" (ibid.,15). This characterization of transitionality, however laconic it may be, already points us toward two salient aspects of Koopman's conception. First, what he has in mind is not change that merely happens, but change that results from the actions of a subject capable of having a purpose (Koopman's examples here are "a hummingbird" and "a man," but perhaps because of pragmatism's inherent humanism he is concerned mostly with humans in his book). ${ }^{9}$ Second, transition is not only made in some "historical circumstances," but is made of these circumstances in the sense that they constitute its "content," just as "temporality is [its] general form" (ibid., 15).

Therefore, from Koopman's point of view, it does not make any sense for philosophers to talk about anything that humans do, or make, in ahistorical, universalist terms, and it would not even be appropriate for them to talk about such matters in historical and local terms if those were understood in an abstract manner, which is sadly the way most philosophers have understood practically everything up until this day. Actually, before philosophers open their mouths to pass judgment on any aspect of human life (which, as Koopman stresses in a Jamesian manner, dwells "in transitions"), they should consult those of their academic colleagues who deal with the stuff of humanity's history on a daily basis-cultural anthropologists, literary critics, sociologists, and, of course, historians. Only then will they be able to become authentic historicists instead of merely paying lip service to contingency while in fact worshiping foundationalist dogma. But wouldn't they be then, a suspicious critic might ask, merely paying lip service to philosophy while actually practicing history, cultural anthropology, or any other discipline to which they would resort in their quest for the particular and contingent? For Koopman, the answer is a sound 'no' as his transitionalist pragmatism is supposed to provide a certain philosophical matrix or framework, a conceptual architecture that would be able not only to synthesize insights provided by the aforementioned fields, to situate them in a wider and more self-reflective perspective, but also to put them to work for a better future of humanity through engaged "cultural critique." This latter approach is, of course, known to all pragmatists under the name of "meliorism," and what is important for us here, in Koopman's mind, transitionalism and meliorism are intimately connected. As he puts it:

If transitionalism connotes merely purposive change, then meliorism connotes purposive change for the better. The two outlooks are obviously complementary: meliorism standing for the attitude of improvement, progress, and betterment at the heart of pragmatist cultural critique and transitionalism for the temporal and historical perspective within which this meliorist cultural critique is situated (Koopman 2009, 17).

\footnotetext{
9 Which, of course, does not mean that pragmatists neglect the animal perspective entirely. See, e.g., McKenna and Light.
} 
Bettering the world is undoubtedly a commendable task, yet in his book Koopman in fact concentrates rather on bettering his own academic discipline (pragmatism in particular), which seems a reasonable idea insofar as one's tools (philosophical tools included) need to be in perfect order if one's job is to be done properly; even if at the same time this looks like a common methodological excuse deployed by philosophers in order to postpone the problematic moment of actually proving that their conceptions have a practical value. ${ }^{10}$ I shall return to this question in the conclusion, but for now let us see why contemporary pragmatism needs to be improved and how Koopman attempts to do just that.

Probably the most tired line in the historiography of pragmatism (besides, of course, the one about Peirce changing the name of his philosophy from "pragmatism" to "pragmaticism") 11 is that today the movement is torn between those who cling to classical, experience-oriented pragmatist thought and the followers of a linguistic pragmatist philosophy developed by Rorty and other authors for whom the "e-word" constitutes a philosophical faux pas. The expression "tired line" may, of course, sound a bit condescending, but I have used it not to question the validity of this observation nor to deprecate those who make it (after all, I myself have made it in a few places), but rather to stress how the point is usually approached. What I mean is that (a) very often when we call some claim a "tired line" we do so because it refers to a problem we do not how to solve and which we thus try to avoid by simply not talking about it anymore, and (b) that this is actually the case with the said split in contemporary pragmatism. It is there, it is in many ways noxious, but the only thing we can seemingly do about it, or at least the only thing most of us seem to be doing, is to wring our hands and wait until the cleavage disappears by itself. Unlike most of us, however, Koopman chooses to pitch up and redefine the whole split so that it can be overcome.

He begins his uneasy task by explaining why it would be unwise to side exclusively with either of the camps, particularly as far as their epistemological views are concerned. The problem with classicopragmatists (Dewey, James, and Peirce), and thus with those who are their faithful defenders today, is that in developing their conceptions of experience they fell prey to what Koopman identifies as a foundationalist "givenism," by which term he understands a doctrine that assigns to "immediate experience" the role of the "foundation of our [beliefs] and practices," including "moral," "political," and, most notably, "epistemic" ones (Koopman 2009, 76 ${ }^{12}$ ). Now in case someone thought him to be a rabid classicopragmatism-basher, it is incumbent to add that Koopman does not want to say that Peirce, James, and Dewey were full-blown, dedicated, and declared foundationalists, and he even admits that this would be an unjust assessment insofar as each of them has, in various places in their oeuvre, expressed clearly antifoundationalist convictions. As is easy to see, then, we have just encountered another fissure within pragmatism-this time within classicopragmatism itself_-and Koopman again does not content himself with merely noting its existence, but tries to identify its source and draw a lesson from it.

\footnotetext{
${ }^{10}$ Cf. Sławiński.

${ }^{11}$ Cf. Menand 2001, 351

${ }^{12}$ Citation slightly modified.
} 
His idea as to why classicopragmatists seem to have vacillated between a healthy antifoundationalism and its pathological opposite is that they simply weren't able to recognize the traps that dwelled within their conceptions of immediate experience, not having at their disposal certain sophisticated philosophical instruments that were provided only later by their neopragmatist successors. The latter, in turn, could forge those tools only because their particular place in the history of philosophy fortunately allowed them to couple the antifoundationalist heritage of classicopragmatism with some of the most valuable achievements of analytic thought. To be more exact, their analytic-minded investigations into the relations between language and experience made them aware of the "subtlest" kinds of givenism, which, for the classicopragmatists, never came into view. But that is not all. Another advantage that the linguistic pragmatists have over the classicopragmatists is that the former have presented a more historicist account of our knowledge than the latter, arguing that "knowledge is justified by nothing deeper than just more knowledge as it develops in time in the field of sociolinguistic practice," and "giving up the quest for the grounds of knowledge by favoring instead the project of specifying the field in which knowledge operates" (Koopman 2009, 95). Therefore, instead of exorcising neopragmatism, as they usually do, the contemporary followers of classicopragmatism need rather to learn from it-at least in this regard.

So far so good, yet there still remains "the question" of whether they should "go down the [linguisticist] road" at whose "end" (Koopman 2009, 96) there awaits them Sellars' famous dictum that "all awareness . . . is a linguistic affair" (Sellars 150). Koopman's answer is in the negative since while the concept of language may certainly be a useful weapon against foundationalism, it begins to make more trouble than it's worth if we treat it - as is the case with Rorty and his fellow-neopragmatists - as accounting for the essence of human life. And to prove this, suffice it to point out that, through its hypertrophic linguisticization, neopragmatism "fails to capture the full range of human knowledge," which, apart from "sociolinguistic practice" (to which Rorty and Brandom unjustifiably reduce it) involves also all kinds of "embodied," "artifactual," and, yes, experiential elements that are "non-discursive" and "non-doxastic."13 In sum, what Koopman ultimately wants is neopragmatism's antifoundationalism without linguisticism, and classicopragmatism's experientalism without foundationalism, and the synthesizing formula which, he believes, allows him to achieve it is the following: "language is just a kind of experience" (Koopman 2009, 128), which he expands by proposing to redescribe

the relation between language and experience as analogous to that between a field and a type of action that occurs in that field, or as analogous to a stream and one kind of element composing that stream. On this view-continues Koopman-language is not different from other forms of experience in any deep and instructive way. The view holds that speaking and writing are not

\footnotetext{
${ }^{13}$ The point is actually Barry Allen's, but Koopman fully endorses it in his book: "Allen's view is that knowledge is better understood in light of complex artifactual achievements than in terms of either linguistic or mental states. A well-made bridge is a better example of human knowledge than some justified true belief about some cat on some mat. I take Allen's point that the cat on the mat is more like a parody than a paradigm of knowledge and that philosophers would do well to note this" (Koopman 2009, 99).
} 
radically different from cooking. Or hammering. Or hiking. Or wild-orchid hunting. ${ }^{14}$ There are of course certain obvious important differences separating each of these forms of experience. But these are innocent piecemeal differences and not the sort of ponderous differences that philosophers have often supposed. Once such a view is up and running, it should never occur to us that ask either the foundationalist question of how language represents experience (because language is here part of the field of experience) or the linguisticist question of how language could ever hook up to anything other than more language (because there are all kinds of things in the field of experience that language hooks up with) (ibid., 127).

Without discussing the validity of this view here, let me stress that as far as neopragmatism's and classicopragmatism's approaches to knowledge are concerned, their sins are not confined, at least in Koopman's perspective, to their narrow concentration on, respectively, language and experience as both also fail through being insufficiently transitionalist.

The gist of this charge is that each conceptualizes knowledge as an inherently static relation, where in the case of classicopragmatism it is a relation between experiential givens and our beliefs, and in neopragmatism's case-a relation between one particular epistemic proposition and the remaining propositions that constitute the discursive web in which this proposition is embedded (cf. Koopman 2009, 109). Now even though for each party the respective elements connected by the relation of knowledge are indeed temporal and submerged in historicity (say, no neopragmatist would deny that the aforementioned discursive webs emerge and evolve in time and that each of their ingredients is always historically situated), the relation itself seems to hover, unchanging and majestically inert, above the sublunar realm of time and chance, while every transitionalist epistemology has to see this relation as dynamic or diachronic. In Koopman's own brand of transitionalism, this approach finds its expression in the idea, inspired by William James, that knowledge is best characterized as betting. To be more exact,

Transitionalist epistemology holds that knowledge (like truth) is ever futural and so irreducibly temporal and historical. Knowledge is a tensed relation ever pointing from past to future. This does not mean that we can never know anything about the present. What it means, rather, is that the achievement of knowledge is a futural achievement. Knowledge is a bet made on a future reality. If one makes a bet on rather obvious present fact (for example, that I am seated here in this chair before you), then the payoff is likely to be small. But if one makes a bet on some future act (for example, that if I sit in the chair in such and such a way then I will not have back problems in a month), then the payoff is likely to be greater if I can indeed successfully transition through time from my belief to its object. The value of knowledge does not consist in our recognition of the obvious but in our being able to make successful bets about the unobvious. What mediates between projections and outcomes so as to certify knowledge are not static relations like correspondence, coherence, or the absolute but rather those humble temporal-historical intermediaries that lead us from the present through the past to the future (Koopman 2009, 117).

\footnotetext{
${ }^{14}$ This example is of course an allusion to Rorty's famous autobiographical essay in which he mentions wild-orchid hunting as one his favorite activities when he was a child. See Rorty 1999-W.M.
} 
There are many interesting consequences of this knowledge-as-betting theory (one of them being that epistemic judgments are neither true nor false unless a given situation to which they refer actually takes place), and while practically all of them are of genuine importance, let me confine myself to mentioning Koopman's point that

[t]hese humble temporal-historical relations that lead us from past to future can be construed as the subject matter of historical, sociological, and anthropological inquiries. This helps us see why pragmatists ought to eagerly extend collaborative invitations to those undertaking such inquirers [sic]. Fleshing out our epistemology in collaboration with such inquirers will enable us to dismiss troubled philosophical conceptions such as that of experiential givens or linguistic ubiquity (ibid., 117).

Thanks to this point we have made a full circle, returning to the question of the significance of historical inquiry for philosophy, which Koopman, as I have already indicated, discusses not only in relation to epistemology, but also to other philosophical subdisciplines such as ethics and political theory. Unfortunately due to lack of space I cannot refer here to those latter discussions in detail, ${ }^{15}$ but what I would like to refer to instead, and what also concerns directly the disciplinary matrix of philosophy, is an important lacuna in Koopman's book. Namely, even though he spends much time tracing all sorts of transitionalist elements in pragmatist epistemology, ethics, and political theory, the book does not refer at all to pragmatist aesthetics ${ }^{16}$, while the work of Dewey, Richard Shusterman, and Thomas Alexander leaves no doubt that there is hardly more a transitionalist strand in pragmatism than its aesthetic reflection. And if someone has any doubts in this regard, I could refer them, for instance, to such places in Art as Experience as the one where Dewey locates the "roots" of aesthetic experience in nothing other than the fact that "[1]ife grows when a temporary falling out is a transition to a more extensive balance of the energies of the organism with those of the conditions under which it lives" (Dewey 1987, 20). ${ }^{17}$

\footnotetext{
${ }^{15}$ I shall return briefly to the question of political theory in a moment; and as far as ethics is concerned, let me just say a few words here. First of all, Koopman's starting point is the current debate between deontology and teleology. And although he is careful to emphasize that each position is not without its merits, he makes it clear that both are wrong in that they do not recognize the plenitude of "moral life," focusing, respectively, either on the "outcomes" of our actions or on their "intentions." Therefore, just as was the case with the debate between experientialism and linguisticism, we are in need of a third way, and one position often presented as a suitable candidate is, of course, virtue ethics. But, says Koopman, following Samuel Scheffler and Stanley Rosen, the main problem with virtue ethics is that it is anachronistic, being accustomed primarily to ancient forms of life, which significantly differ from those of today. And they do so mainly through their relative stability as opposed to "the flux of modern moral life" with its "tension" between "individuality and sociality" (Koopman 2009, 153, 141). Koopman's answer to this "impasse" is to propose another "third way"-a pragmatist perfectionism inspired by Stanley Cavell, James, and Dewey.

${ }^{16}$ Even if it briefly touches on pragmatist literary theory as represented by the work of Jonathan Levin, Richard Poirier, and Stanley Fish (Koopman 2009, 67). Admittedly, Koopman does refer to Dewey's Art as Experience, but that reference does not change much since not only is it an isolated one, but it is also entirely subordinated to epistemological matters (Koopman 2009, 199).

${ }^{17}$ Cf., e.g., Shusterman 2000b, 12-13, 19, 24-33, 54-55, 70, 206; Shusterman 2000a, 22; cf. Shusterman 2004, 111.
} 
Given how obvious the transitionality of pragmatist aesthetics is, one can only wonder why Koopman neglects it, and one probable reason I myself could come up with is the fact that his two main pragmatist heroes, William James and Richard Rorty, never developed a full-blown aesthetics, with Rorty even explicitly questioning the very idea of "aesthetics as a discipline" (in an article Koopman actually refers to in his book, without mentioning, however, this particular issue):

This [philosophical aesthetics] has always struck me [says Rorty] as another of Kant's bad ideas - of a piece with the bad idea (to which I think Habermas unfortunately prone) of splitting culture into three spheres, one for each of the three Critiques. Some good books have been written about painting, others about literature, others about music, others about sex, and still others about birdwatching. But I have never read a book that succeeded in saying something interesting about what all these have in common (Rorty 2001, 156).

Whatever his real reasons for the neglect of pragmatist aesthetics, another, and more important, lack in Koopman's book is that it says virtually nothing about how his transitionalism might solve any concrete extra-philosophical problems, ${ }^{18}$ which, if not something one usually faults a philosophical text for, is a bit baffling for a work that emphasizes on every possible occasion that "pragmatists are above all concerned with melioration-with how we can make our lives better than they presently are," and chides other works and conceptions for relying on "armchair intuitions," for "lack of engagement with concrete political realities", or for having "no bearing on actual practical conduct" (Koopman 2009, 145, 123, 113).

To be sure, Koopman himself admits that more practical applications of transitionalism shall be contained in his subsequent works, and that in Pragmatism as Transition he is concerned with something "different," (namely, with "explicating" how such applications "might" look in theory and why non-transitionalist philosophies are useless in practice), but this means that an adequate adjudication of his project must wait until those other articles and books appear (see Koopman 2009, 35). To explain my point further, let me underscore that what Koopman has succeeded in for now are mainly (some would surely say, "merely") his criticisms of various foundationalist, essentialist strands in pragmatism and in other schools of contemporary philosophy. And while this is not an easy feat in itself, and we should all admire the wit, acuity, and erudition with which he accomplishes it, note how Koopman

\footnotetext{
${ }_{18}$ And when it in fact says something of the sort, the point is usually too general, sketchy, or watereddown to be of any real use. The following passage is especially instructive in this regard: "To summarize the core of this transitionalist meliorism, allow me to conclude with a distinction. Consider that the facts of our present political situation, say the current state of debates on heteronormative sexuality, can be interpreted in at least two ways. Taken purely logically, we might find current cultural opinion both intractable and difficult to work with insofar as it is difficult to understand on a purely logical basis how we might persuade those who enforce heteronormativity to adopt some other perspective on modern sexual practice. But taken historically, as a situation with a precise historical trajectory that both comes from somewhere and is going in some definite direction, we might be more hopeful about the possible future of modern sexuality and more aware of ways in which we might engage in these debates in order to nudge them along in the directions in which most everyone is already going" (Koopman 2009, 172).
} 
criticizes other positions for stemming from, and addressing exclusively, some technical scholastic problems and not the stuff of life's praxis, which is ironically an argument one can level against his own book.

For what are the questions of immediate experience vs. sociolinguistic practices (in political theory and epistemology), or of Kantian teleology vs. utilitarianism (in ethics)- to name just two of those which Koopman addresses, if not endemic, technical problems that nobody besides professional philosophers can care about? And that they are so can be demonstrated in a simple way by recalling the conclusions to which Koopman is led by pondering on them. In criticizing Cheryl Misak's and Robert Talisse's overly languageoriented "deliberative democratic theory," for instance, he observes in conclusion:

\begin{abstract}
Although the epistemic virtues of reason giving and justification offering are indeed important for democratic practice, there are indeed other virtues of democratic practice. A viable pragmatist philosophy of democracy must take account of the complex constitution of democratic practice and affirm the multiple intersections between deliberation and other political practices" such as "marching, demonstrating, boycotting, hunger striking or even voting (ibid., 183).
\end{abstract}

While there certainly are, as we see, some political theorists whose eyes need to be opened to the importance of non-deliberative practices for democracy, this importance surely does not need to be revealed to any political activist. One can actually very easily imagine such a person responding to the above citation with the following words: "Whoa, so these are those enlightening ideas you philosophers are working on? Sorry, but we've known this all along. Come back when you invent something really useful." These very same words, moreover, might be uttered by a scientist in reaction to passages from Pragmatism as Transition such as "Forms of epistemic success do not stand in need of any grounding above and beyond all those ordinary details we employ in our everyday inquiries: lab tables, notebooks, sophisticated technical equipment, peer-review mechanisms, subtle but crucial networks of affiliation, research journals, persuasive rhetoric, and, yes, even sentences" (Koopman 2009, 129), and, yes, the list of such passages could go on for quite a while.

The above reservations, however, do not change my general impression, which I would like to stress here, that Koopman's is an excellent, thought-provoking book that anyone interested in where pragmatism is currently heading should read. It is so good, in fact, that I already look forward to its sequel, in which, I hope (a word that figures prominently in Pragmatism as Transition) Koopman's philosophical tools will actually be applied to the praxis of life.

\title{
References
}

Dewey, J. Art as Experience: The Later Works, 1925-1953, Volume 10. In Jo Ann Boydston (Ed.). Carbondale: Southern Illinois University Press, 1987.

Haack, S. Manifesto of a Passionate Moderate: Unfashionable Essays. Chicago: University of Chicago Press, 1998.

McKenna, E., Light, A. (Eds.). Animal Pragmatism: Rethinking Human-Nonhuman Relationships. Bloomington, IN: Indiana University Press, 2004. 
Małecki, W. Von nicht-diskursiver Erfahrung zur Somästhetik: Shusterman über Dewey und Rorty. Translated into German by Urszula Kawalec. Deutsche Zeitschrift für Philosophie, No. 5, 677-90, 2008.

Małecki, W. Embodying Pragmatism: Richard Shusterman's Philosophy and Literary Theory. Frankfurt am Main-New York: Peter Lang, 2010.

Menand, L. The Metaphysical Club: A Story of Ideas in America. New York: Farrar, Straus, and Giroux, 2001.

Rorty, R. Consequences of Pragmatism. Minneapolis: University of Minnesota Press, 1982.

Rorty, R. Contingency, Irony, and Solidarity. Cambridge: Cambridge University Press, 1989.

Rorty, R. Essays on Heidegger and Others: Philosophical Papers, Volume 2. Cambridge: Cambridge University Press, 1991.

Rorty, R. Objectivity, Relativism, and Truth: Philosophical Papers. Volume 1. Cambridge: Cambridge University Press, 1991.

Rorty, R. Relativism-Finding and Making. In J. Niżnik and J. T. Sanders (Eds.). Debating the State of Philosophy: Habermas, Rorty, and Kotakowski. Westport: Praeger Paperback, 31-47, 1996.

Rorty, R. Response to Richard Shusterman. In M. Festenstein, S. Thompson (Eds.). Richard Rorty: Critical Dialogues. Cambridge: Polity Press, 153-7, 2001.

Rorty, R. Philosophy as Cultural Politics. Cambridge: Cambridge University Press, 2007.

Rorty, R. Trotsky and Wild Orchids. In Philosophy and Social Hope. London: Penguin, 1999.

Sellars, W. Empiricism and the Philosophy of Mind. Cambridge, Mass.: Harvard University Press, 1997.

Shusterman, R. Complexities of Aesthetic Experience: Response to Johnston. Journal of Aesthetic Education, No. 4, 109-12, 2004.

Shusterman, R. Performing Live: Aesthetic Alternatives for the Ends of Art. Ithaca: Cornell University Press, 2000a.

Shusterman, R. Pragmatist Aesthetics: Living Beauty, Rethinking Art, 2nd ed. New York: Rowman and Littlefield, 2000b.

Sławiński, J. Zwłoki metodologiczne [Methodological Delays]. In Teksty i teksty. Kraków: Universitas, $45-53,2000$.

Faculty of Philology,

University of Wrocław,

Plac Nankiera 15,

50-140 Wrocław,

Poland

Tel.: (48-071) 3752039

E-mail: wojciech.malecki_at_wp.pl 